\title{
Analisis Kebutuhan Bahan Ajar Biologi untuk Siswa SMA Ditinjau dari Tingkat Kesulitan Materi, Keterampilan Berpikir Tingkat Tinggi, dan Keaktifan Belajar Siswa
}

\author{
Nurul Zakiyatin Nisak ${ }^{1^{*}}$ \\ ${ }^{1}$ Prodi Pendidikan Biologi, Fakultas Pascasarjana, Universitas Negeri Malang \\ *email: nurulzakiyana@gmail.com
}

\begin{tabular}{l} 
Article History \\
\hline Received: \\
23/04/2021 \\
Revised: \\
24/05/2021 \\
Accepted: \\
08/06/2021
\end{tabular}

Kata kunci:

Analisis

kebutuhan

Bahan ajar

Biologi SMA

Kebutuhan

bahan ajar

Materi biologi

Key word:

Needs analysis

Teaching

materials

Biology for high

school

Teaching material needs

Biology material

\begin{abstract}
ABSTRAK
Tujuan penelitian ini yakni untuk mengetahui kebutuhan bahan ajar dalam pembelajaran biologi di SMA dilihat dari tingkat kesulitan materi menurut siswa, pengembangan keterampilan berpikir tingkat tinggi melalui kegiatan pembelajaran, serta keaktifan siswa dalam mengikuti pembelajaran. Penelitian ini merupakan penelitian deskriptif kualitatif yang dilakukan pada bulan Mei 2018 di Bandar Lampung. Teknik keabsahan data menggunakan triangulasi sumber dan metode. Data dikumpulkan melalui observasi, wawancara, dan dokumentasi menggunakan angket. Data dianalisis menggunakan analisis deskriptif dan persentase jawaban angket. Hasil penelitian menunjukkan bahwa (1) siswa mengalami kesulitan dalam mempelajari materi jaringan hewan $(55.71 \%)$, jaringan tumbuhan $(54.29 \%)$, sistem gerak $(54.29 \%)$, sel $(48.57 \%)$, sistem peredaran darah $(42.86 \%)$, dan sistem koordinasi (32.86\%); (2) pembelajaran biologi yang dilakukan belum mampu mengembangkan keterampilan berpikir tingkat tinggi secara optimal; dan (3) siswa kurang aktif dalam mengikuti kegiatan pembelajaran. Kesimpulan dari penelitian ini yaitu dibutuhkan bahan ajar biologi untuk SMA yang dapat mengatasi kesulitan siswa, mengembangkan keterampilan berpikir tingkat tinggi, dan meningkatkan keaktifan/keterlibatan siswa dalam pembelajaran.
\end{abstract}

Copyright $@ 2021$ LPPM Universitas Indraprasta PGRI. All Right Reserved

\section{PENDAHULUAN}

Efektivitas dalam pembelajaran salah satunya dipengaruhi oleh bahan ajar yang digunakan. Bahan ajar merupakan segala bentuk bahan yang digunakan untuk membantu guru melaksanakan kegiatan pembelajaran berupa seperangkat materi yang disusun sistematis untuk memudahkan siswa
(Direktorat Pembinaan SMA, 2010). Menurut Sadjati (2012), bahan ajar bersifat sangat unik dan spesifik. Artinya, bahan ajar memang dirancang sedemikian rupa hanya untuk mencapai tujuan tertentu dari siswa tertentu. Sistematika cara penyampaian bahan ajar disesuaikan dengan karakteristik mata pelajaran dan karakteristik siswa yang menggunakannya. Bahan ajar menjadi 
salah satu faktor penting yang menentukan efektif tidaknya suatu pembelajaran (Arsanti, 2018).

Mata pelajaran biologi merupakan salah satu muatan sains dan teknologi yang dipelajari oleh siswa SMA/MA berdasarkan Kurikulum 2013. Biologi merupakan ilmu yang mempelajari segala sesuatu tentang makhluk hidup. Ruang lingkup materi biologi pada jenjang SMA berkaitan dengan makhluk hidup itu sendiri, interaksi antara makhluk hidup dan lingkungan, proses-proses yang terjadi dalam tubuh mahkluk hidup, dan bioteknologi. Sifat objek materi yang dipelajari dalam biologi sangat beragam, baik ditinjau dari ukuran (makroskopis dan mikroskopis), keterjangkauan (ekosistem kutub, padang pasir, tundra, dan lainnya), keamanannya (bakteri/virus yang bersifat patogen), bahasa (penggunaan Bahasa Latin dalam nama ilmiah), dan sebagainya (Sudarisman, 2015).

Materi biologi sering kali dipandang siswa sebagai materi yang sulit dipelajari (Cimer, 2012; Raida, 2018). Terdapat berbagai alasan yang menyebabkan materi biologi sulit bagi siswa (Tekkaya et al., 2001; Zeidan, 2010). Salah satunya yaitu penggunaan Bahasa Latin dalam biologi membuat siswa menjadi kesulitan dalam mempelajari materi (Ozcan et al., 2013). Selain itu, permasalahan pada buku teks yang digunakan juga menjadi salah satu faktor yang membuat siswa kesulitan mempelajari biologi (Tekkaya et al., 2001). Kesulitan-kesulitan tersebut dapat berdampak negatif pada motivasi dan prestasi siswa (Ozcan et al., 2013).

Materi biologi memerlukan keterampilan berpikir tingkat tinggi atau Higher Order Thinking Skill (HOTS) dalam mempelajarinya (Sudarisman, 2015). Keterampilan tersebut sedang diupayakan oleh Kurikulum 2013 untuk menjawab tuntutan pendidikan abad 21. Sebagai salah satu tuntutan abad 21, keterampilan berpikir tingkat tinggi menurut Greenstein (2012) meliputi: berpikir kritis (critical thinking), pemecahan masalah (problem solving), kreativitas (creativity), dan metakognisi (metacognition).

Meskipun telah diupayakan dalam kurikulum 2013, faktanya, keterampilan berpikir tingkat tinggi siswa pada materi biologi masih tergolong rendah (Angraini \& Sriyati, 2019; Yulianis et al., 2019). Banyak penelitian yang dilakukan di Indonesia menunjukkan bahwa keterampilan berpikir kritis siswa masih rendah (Subiantoro \& Fatkurohman, 2009; Surata et al., 2013; Fatmawati et al., 2014; Hidayati, 2016; Lestari et al., 2016; Susilowati et al., 2017; Yulianis et al.,
2019; Nuraini \& Suparman, 2018). Ditemukan pula keterampilan pemecahan masalah pada siswa masih perlu ditingkatkan (Kurniawan, 2015; Kurniawati et al., 2019; Yulianis et al., 2019), keterampilan berpikir kreatif yang masih perlu dikembangkan (Lisliana et al., 2016; Yulianis et al., 2019; Nuraini \& Suparman, 2018), dan keterampilan metakognisi belum berkembang secara optimal (Nurman et al., 2018; Wardawaty et al., 2018).

Permasalahan yang juga ditemukan dalam berbagai penelitian yakni rendahnya tingkat keterlibatan/keaktifan siswa dalam mengikuti pembelajaran (Ni'mah, 2017; Irsyad et al., 2020; Naziah et al., 2020). Sedangkan, pembelajaran sesuai dengan Kurikulum 2013 diarahkan pada penciptaan suasana aktif, kritis, analisis, dan kreatif dalam pemecahan masalah melalui pengembangan keterampilan berpikir. Dengan kata lain, siswa juga harus terlibat aktif dalam mengikuti kegiatan pembelajaran (Ozcan et al., 2013). Dengan terlibat aktif, siswa dapat mempelajari materi lebih baik, mengetahui kesalahannya, memperbaiki kesalahannya, dan lebih termotivasi untuk belajar. Selain itu, keaktifan siswa dalam pembelajaran sangat berpengaruh pada proses pengembangan keterampilan berpikir (Wibowo, 2016). Karena itu, keaktifan siswa juga menjadi salah satu faktor penting dalam keberhasilan pembelajaran.

Berdasarkan hal-hal yang telah dipaparkan, dilakukanlah penelitian untuk mengetahui kebutuhan bahan ajar biologi SMA dilihat dari karakteristik materi dan karakteristik siswa. Karakteristik yang dimaksud dalam penelitian ini yakni tingkat kesulitan materi menurut siswa beserta alasannya, pengembangan keterampilan berpikir tingkat tinggi milik siswa melalui kegiatan pembelajaran, serta keaktifan siswa dalam mengikuti kegiatan pembelajaran.

\section{METODE PENELITIAN}

Penelitian ini merupakan penelitian deskriptif kualitatif yang dilakukan pada bulan Mei 2018. Sampel diambil secara acak sebanyak 70 siswa kelas XI SMA Negeri 2 Bandar Lampung tahun ajaran 2018/2019 dan 1 guru biologi. Teknik keabsahan data menggunakan triangulasi sumber dan metode. Data dikumpulkan melalui observasi, wawancara guru biologi, dan dokumentasi menggunakan angket (kuesioner) analisis kebutuhan siswa. Data dianalisis menggunakan analisis deskriptif kualitatif dari jawaban guru dan 
persentase dari hasil jumlah jawaban yang diberikan responden dibagi jumlah seluruh responden dikali $100 \%$. Secara sistematis, persentase yang diperoleh dari angket siswa dihitung melalui persamaan:

Persentase $=\frac{\text { jumlah jawaban yang diperoleh }}{\text { jumlah seluruh responden }} \times 100 \%$

\section{HASIL DAN PEMBAHASAN}

Analisis kebutuhan sumber belajar dan media pembelajaran biologi SMA dalam penelitian ini dilakukan dengan pemberian angket siswa dan wawancara guru biologi. Hasil yang ditemukan berkaitan dengan tingkat kesulitan materi menurut siswa, pengembangan keterampilan berpikir tingkat tinggi yang masih kurang optimal, dan keaktifan siswa yang masih perlu ditingkatkan.

Berdasarkan hasil angket, tingkat kesulitan materi biologi kelas XI menurut siswa dapat dilihat pada Tabel 1.

Tabel 1. Tingkat kesulitan materi menurut siswa

\begin{tabular}{lcc}
\hline \multicolumn{1}{c}{ Materi } & $\begin{array}{c}\text { Persentase } \\
(\mathbf{\%})\end{array}$ & $\begin{array}{c}\text { Tersulit } \\
\text { ke- }\end{array}$ \\
\hline Sel & 48.57 & 4 \\
Jaringan tumbuhan & 54.29 & 2 \\
Jaringan hewan & 55.71 & 1 \\
Sistem gerak & 54.29 & 2 \\
Sistem peredaran darah & 42.86 & 5 \\
Sistem pencernaan & 8.57 & 8 \\
Sistem respirasi & 1.43 & 11 \\
Sistem ekskresi & 5.71 & 10 \\
Sistem koordinasi & 32.86 & 6 \\
Sistem reproduksi & 17.14 & 7 \\
Sistem imun & 8.57 & 8 \\
\hline
\end{tabular}

Jaringan hewan dianggap sebagai materi tersulit oleh $55.71 \%$ siswa, sedangkan jaringan tumbuhan dan sistem gerak dianggap materi tersulit ke-2 oleh $54.29 \%$ siswa. Materi sel, sistem peredaran darah, dan sistem koordinasi masing-masing dianggap sulit oleh $48.57 \%, 42.86 \%$, dan $32.86 \%$ siswa. Sedangkan materi sistem reproduksi, sistem imun, sistem pencernaan, sistem ekskresi, dan sistem respirasi dianggap sulit oleh sebagian kecil siswa yakni $17.14 \%, 8.57 \%, 8.57 \%, 5.71 \%$, dan $1.43 \%$ dari total jumlah responden siswa.

Materi jaringan hewan dianggap sulit karena terdapat banyak istilah asing/latin yang perlu dihafal. Banyaknya hafalan memang merupakan salah satu alasan yang sering diungkapkan oleh siswa sebagai kesulitan dalam mempelajari biologi (Ozcan et al., 2013). Selain itu, istilah asing/latin yang merupakan salah satu karakteristik materi biologi juga menjadi alasan mengapa biologi dianggap sulit (Cimer, 2012; Ozcan et al., 2013).

Materi sistem gerak dianggap sulit dipelajari karena terdapat banyak hafalan nama-nama tulang yang merupakan istilah asing/latin. Selain itu, sistem gerak juga dianggap sulit karena tulangtulang penyusunnya susah dibedakan jika melihat gambar yang ada di buku. Visualisasi yang terdapat dalam bahan belajar, media belajar, ataupun sumber belajar yang digunakan juga berkontribusi dalam kemudahan/kesulitan siswa mempelajari biologi. Jika tidak ada visualisasi ataupun visualisasi materi tidak jelas maka akan menyulitkan siswa dalam mempelajari biologi (Ozcan et al., 2013).

Materi sistem peredaran sulit dipelajari karena materinya terlalu banyak dan kompleks sehingga sulit dipahami. Materi biologi merupakan salah satu mata pelajaran yang memiliki konsep dan permasalahan yang kompleks (Cimer, 2012; Zamzami, 2020). Kompleksitas materi biologi inilah yang menjadi salah satu alasan siswa mengalami kesulitan dalam mempelajarinya (Cimer, 2012; Etobro \& Fabinu, 2017). Selain itu, banyaknya detail membuat materi biologi menjadi sulit (Ozcan et al., 2013).

Alasan siswa menganggap materi biologi sulit dapat dilihat dalam Tabel 2.

Tabel 2. Anggapan siswa tentang materi biologi

\begin{tabular}{lc}
\hline \multicolumn{1}{c}{ Anggapan Siswa } & $\begin{array}{c}\text { Persentase } \\
(\mathbf{\%})\end{array}$ \\
\hline Materi terlalu banyak dan kompleks & 51.43 \\
Biologi banyak hafalan & 48.57 \\
Biologi banyak istilah sulit & 40.00 \\
Materi sulit dipahami dan & 15.71 \\
dibayangkan & \\
\hline
\end{tabular}

Anggapan $48.57 \%$ siswa yang menyatakan bahwa biologi banyak hafalan dan $40 \%$ siswa yang menyatakan bahwa biologi banyak istilah sulit menunjukkan bahwa siswa masih terbiasa untuk hanya menghafal istilah dan konsep. Menghafal atau mengingat (recall) merupakan salah satu dimensi remember $(\mathrm{C} 1)$ yang merupakan tingkat berpikir paling rendah (Karthwohl, 2002). Sedangkan, keterampilan berpikir tingkat tinggi tidak hanya mengingat, namun juga membutuhkan keterampilan lebih tinggi, seperti analisis, evaluasi, dan mencipta (Angraini \& Sriyati, 2019).

Sebagian besar siswa $(51.43 \%)$ mengungkapkan bahwa materi biologi terlalu banyak dan kompleks. Kompleks disini dalam artian materi biologi dianggap sulit karena terlalu rumit. Sebagian siswa $(15.71 \%)$ juga menyatakan 
bahwa materi sulit dipahami dan dibayangkan. Pernyataan siswa tersebut menunjukkan bahwa siswa mengalami kesulitan dalam memahami atau understand $(\mathrm{C} 2)$ yang hanya satu tingkat lebih tinggi dari remember (Karthwohl, 2002). Sedangkan, keterampilan berpikir tingkat tinggi (high order thinking skills) merujuk pada aktivitas menganalisis, mengevaluasi, dan mencipta pengetahuan (Wahyuningsih et al., 2019) yang berada pada tingkat $\mathrm{C} 4, \mathrm{C} 5$, dan C6 dalam taksonomi Bloom (Karthwohl, 2002). Artinya, siswa masih belum terlatih untuk berpikir tingkat tinggi. Pernyataan ini juga didukung dengan hasil wawancara guru biologi kelas XI yang menyatakan bahwa keterampilan berpikir tingkat tinggi pada $33 \%$ siswa masih perlu ditingkatkan.

Temuan penelitian ini sesuai dengan hasil penelitian terdahulu yang menyatakan bahwa keterampilan berpikir tingkat tinggi siswa masih rendah (Angraini \& Sriyati, 2019; Yulianis et al., 2019). Salah satu penyebabnya yaitu sebagian besar soal latihan masih berada pada tingkat $\mathrm{C} 2$ (Yulianis et al., 2019), sebagian kecil pada tingkat C4 dan C5, namun tidak ditemukan soal pada tingkat C6 (Angraini \& Sriyati, 2019). Hal ini menunjukkan bahwa pelatihan soal pada tingkat C4, C5, dan C6 penting untuk mengembangkan keterampilan berpikir tingkat tinggi pada siswa (Yulianis et al., 2019).

Permasalahan lain yang ditemukan yakni berkaitan dengan kegiatan pembelajaran. Berdasarkan hasil wawancara guru biologi diketahui bahwa pembelajaran biologi dilakukan dengan berbagai metode. Namun, $17.14 \%$ siswa mengemukakan bahwa pembelajaran biologi hanya dilakukan dengan metode ceramah. Ketidaksesuaian ini menunjukkan bahwa beberapa siswa kurang aktif dalam mengikuti kegiatan pembelajaran. Sedangkan, keterlibatan siswa secara aktif dalam kegiatan pembelajaran sangat berpengaruh pada proses pengembangan keterampilan berpikir (Wibowo, 2016). Hal ini didukung dengan adanya pernyataan siswa bahwa pembelajaran yang dilakukan membosankan atau biasa saja sehingga berdampak pada pemahaman mereka terhadap materi yang kurang hingga cukup.

Permasalahan yang berkaitan dengan kegiatan pembelajaran juga ditunjukkan dari pernyataan $37.14 \%$ siswa yang mengemukakan bahwa pembelajaran biologi hanya dilakukan dengan metode presentasi. Metode presentasi biasanya diawali dengan metode diskusi (Marpaung, 2018), seperti yang dikemukakan oleh siswa lain. Artinya, siswa yang beranggapan bahwa pembelajaran dilakukan hanya dengan metode presentasi merupakan siswa yang kurang aktif dalam kegiatan diskusi (kegiatan pembelajaran) sehingga berdampak pula pada pemahaman terhadap materi yang kurang hingga cukup. Temuan penelitian ini sesuai dengan hasil penelitian terdahulu yang menyatakan bahwa siswa masih kurang berpartisipasi aktif dalam kegiatan pembelajaran (Ni'mah, 2017; Angraini \& Sriyati, 2019; Irsyad et al., 2020; Naziah et al., 2020). Rendahnya keterlibatan siswa secara aktif dalam pembelajaran ini dapat menyebabkan rendahnya keterampilan berpikir tingkat tinggi pada siswa (Angraini \& Sriyati, 2019).

Permasalahan lain yang ditemukan juga berkaitan dengan sumber belajar yang digunakan siswa. Berdasarkan hasil angket analisis kebutuhan siswa diketahui bahwa sebesar $21.43 \%$ siswa tidak memiliki sumber belajar berupa buku paket biologi kelas XI. Ditemukan pula bahwa siswa yang mempelajari berbagai buku mengalami kebingungan karena adanya perbedaan konsep pada buku-buku yang dipelajari. Siswa juga mengalami kesulitan dalam mempelajari buku karena gambar dan penjelasan konsepnya sangat kompleks dan tidak mudah dipahami. Temuan ini sesuai dengan hasil penelitian Tekkaya et al. (2001) yakni permasalahan pada buku teks yang digunakan juga menjadi salah satu faktor yang membuat siswa kesulitan mempelajari biologi.

Temuan penelitian secara keseluruhan berkaitan dengan kesulitan siswa dalam mempelajari materi biologi, pengembangan keterampilan berpikir tingkat tinggi melalui kegiatan pembelajaran yang masih kurang optimal, dan keaktifan/keterlibatan siswa dalam kegiatan pembelajaran yang masih perlu ditingkatkan. Kesulitan/kemudahan siswa mempelajari biologi salah satunya ditentukan oleh penggunaan bahan ajar yang sesuai dengan kebutuhan belajar. Bahan ajar merupakan salah satu faktor penting yang dapat meningkatkan kualitas pembelajaran (Sadjati, 2012). Oleh karena itu, dibutuhkan pengembangan bahan ajar yang sesuai dengan karakteristik materi ataupun karakteristik siswa.

\section{KESIMPULAN}

Sebagian besar siswa mengalami kesulitan dalam mempelajari materi jaringan hewan $(55.71 \%)$, jaringan tumbuhan $(54.29 \%)$, sistem gerak $(54.29 \%)$, sel $(48.57 \%)$, sistem peredaran darah $(42.86 \%)$, dan sistem koordinasi $(32.86 \%)$. Alasan siswa menganggap materi biologi tersebut 
sulit bermacam-macam. Sebagian besar siswa menganggap bahwa materi terlalu banyak dan kompleks (51.43\%), banyak hafalan (48.57\%), banyak istilah sulit (40\%), dan materi sulit dipahami dan dibayangkan (15.71\%). Anggapananggapan tersebut menunjukkan bahwa siswa masih terbiasa hanya menghafal istilah dan konsep. Menghafal merupakan tingkat berpikir paling rendah. Artinya, siswa masih belum terbiasa untuk berpikir tingkat tinggi. Selain itu, siswa juga kurang aktif dalam mengikuti kegiatan pembelajaran. Oleh karena itu, perlu dilakukan pengembangan bahan ajar biologi SMA yang sesuai dengan karakteristik materi dan kebutuhan siswa.

\section{DAFTAR PUSTAKA}

Angraini, G., \& Sriyati, S. (2019). Analisis kemampuan berpikir tingkat tinggi siswa SMAN kelas $\mathrm{X}$ di Kota Solok pada konten biologi. Journal of Education Informatic Technology and Science, 1(1), 114-124.

Arends, R. (2012). Learning to Teach. 9th Ed. McGraw-Hill: New York.

Arsanti, M. (2018). Pengembangan bahan ajar mata kuliah penulisan kreatif bermuatan nilainilai pendidikan karakter religius bagi mahasiswa Prodi PBSI, FKIP, UNISSULA. Jurnal KREDO, 1(2), 71-90.

Cimer, A. (2012). What makes biology learning difficult and effective: students' views. Educational Research and Reviews, 7(3), 6171.

Direktorat Pembinaan SMA. (2010). Juknis Pengembangan Bahan Ajar SMA. Kementerian Pendidikan dan Kebudayaan: Jakarta.

Etobro, A. B., \& Fabinu, O. E. (2017). Students' perceptions of difficult concepts in biology in senior secondary schools in Lagos State. Global Journal of Educational Research, 16, 139-147.

Fatmawati, H., Mardiyana., \& Triyanto. (2014). Analisis berpikir kritis siswa dalam pemecahan masalah matematika berdasarkan pola pada pokok bahasan persamaan kuadrat. Jurnal Elektronik Pembelajaran Matematika, 2(9), 899-910.

Greenstein, L. M. (2012). Assessing $21^{\text {st }}$ Century Skills: A Guide to Evaluating Mastery and Authentic Learning. Corwin: California.

Hidayati, N. (2016). Hasil Belajar dan Keterampilan Berpikir Kritis Siswa Madrasah Tsanawiyah dalam Pembelajaran IPA Melalui Kerja Ilmiah. In Biology Education
Conference: Biology, Science, Enviromental, and Learning (pp. 118-127). Surakarta, Indonesia: Biology Education Department, Universitas Sebelas Maret.

Irsyad, T., Wuryandini, E., Yunus, M., \& Hadi, D. P. (2020). Analisis keaktifan mahasiswa dalam proses pembelajaran statistika multivariat. Jurnal Pendidikan Ekonomi Undiksha, 12(1), 89-96.

Karthwohl, D. R. (2002). Revision of bloom's taxonomy: an overview. Theory Into Practice, 41(4), 212-218.

Kurniawan, H. (2015). Analisis Keterampilan Pemecahan Masalah pada Pembelajaran Matematika. In Seminar Nasional Pendidikan Meretas Sukses Publikasi Ilmiah Bidang Pendidikan Jurnal Bereputasi (pp. 67-73). Surakarta, Indonesia: Universitas Sebelas Maret.

Kurniawati, M., Sajidan., \& Ramli, M. (2019). Analisis Keterampilan Memecahkan Masalah Siswa SMA. In Biology Education Conference (pp. 75- 78). Surakarta, Indonesia: Universitas Sebelas Maret.

Lestari, A., Tindangen, M., \& Akhmad. (2016). Analisis Kemampuan Berpikir Kritis dengan Model Pembelajaran Inkuiri pada Pembelajaran Biologi Kelas VII-A SMP Negeri 3 Long Kali tahun ajaran 2015/2016. In Seminar Nasional II Biologi, Sains, Lingkungan, dan Pembelajaran (pp. 355-373). Samarinda, Indonesia: Program Studi Pendidikan Biologi, FKIP, Universitas Mulawarman.

Lisliana., Hartoyo, A., \& Bistari. (2016). Analisis kemampuan berpikir kreatif siswa dalam menyelesaikan masalah pada materi segitiga di SMP. Jurnal Pendidikan dan Pembelajaran Khatulistiwa, 5(11), 1-11.

Marpaung, D. (2018). Penerapan metode diskusi dan presentasi untuk meningkatkan minat dan hasil belajar siswa di kelas XI IPS-1 SMA Negeri 1 Bagan Sinembah. School Education Journal, 8(4), 360-368.

Naziah, S. T., Maula, L. H., Sutisnawati, A. (2020). Analisis keaktifan belajar siswa selama pembelajaran daring pada masa Covid-19 di Sekolah Dasar. Jurnal JPSD, 7(2), 109-120.

Ni'mah, F. (2017). Penerapan strategi pembelajaran active knowledge sharing disertai media video untuk meningkatkan keaktifan belajar IPA siswa kelas VII. Jurnal Profesi Keguruan, 3(1), 43-59. 
Nuraini, R., \& Suparman. (2018). Deskripsi Kemampuan Berpikir Kritis dan Kreatif Siswa Melalui Penerapan Pendekatan Saintifik. In Seminar Nasional Pendidikan Matematika Etnomatnesia (pp. 702-707). Yogyakarta, Indonesia: Universitas Sarjanawiyata Tamansiswa.

Nurman, R., Hala, Y., \& Bahri, A. (2018). Profil Keterampilan Metakognitif dan Sikap Ilmiah Mahasiswa Jurusan Biologi FMIPA UNM. In Seminar Nasional Biologi dan Pembelajarannya (pp. 371-376). Makassar, Indonesia: Jurusan Biologi, FMIPA, Universitas Negeri Makassar.

Ozcan, T., Ozgur, S., Kat, A., \& Elgun, S. (2013). Identifiying and comparing the degree of difficulties biology subjects by adjusting it is reasons in elemantary and secondary. ProcediaSocial and Behavioral Sciences, 116, 113-122.

Raida, S. A. (2018). Identifikasi materi biologi SMA sulit menurut pandangan siswa dan guru SMA Se-Kota Salatiga. Journal of Biology Education, 1(2), 2009-2022.

Sadjati, I. M. (2012). Pengembangan Bahan Ajar. In Hakikat Bahan Ajar (pp. 1-62). Universitas Terbuka: Jakarta.

Subiantoro, A. W., \& Fatkurohman, B. (2009). Keterampilan berpikir kritis siswa dalam pembelajaran biologi menggunakan media koran. Jurnal Pendidikan Matematika dan Sains, 14(2), 111-114.

Sudarisman, S. (2015). Memahami hakikat dan karakteristik pembelajaran biologi dalam upaya menjawab tantangan abad 21 serta optimalisasi implementasi Kurikulum 2013. Jurnal Florea, 2(1), 29-35.

Surata, I. N., Kustoro, B., \& Abdurahman. (2013). Analisis keterampilan berpikir kritis siswa berdasarkan model siklus belajar dan penalaran formal. Jurnal Teknologi Informasi Komunikasi Pendidikan, 1(3), 1-15.

Susilowati., Sajidan., \& Ramli, M. (2017). Analisis Keterampilan Berpikir Kritis Siswa Madrasah
Aliyah Negeri di Kabupaten Magetan. In Seminar Nasional Pendidikan Sains (pp. 223-231). Surakarta, Indonesia: Universitas Sebelas Maret.

Tekkaya, C., Özkan, Ö., \& Sungur, S. (2001). Biology concepts perceived as difficult by turkish high school students. Journal of Hacettepe University Education Faculty, 21, 145-150.

Wahyuningsih,Y., Rachmawati, I., Setiawan, A., \& Ngazizah, N. (2019). HOTS (High Order Thinking Skills) dan Kaitannya dengan Keterampilan Generik Sains dalam Pembelajaran IPA SD. In Seminar Nasional Pendidikan (SNDIK) I (pp. 227-234). Surakarta, Indonesia: Universitas Muhammadiyah Surakarta.

Wardawaty, Arsyad, N., \& Alimuddin. (2018). Analisis Keterampilan Metakognitif dalam Pemecahan Masalah Matematika Ditinjau dari Gaya Kognitif. Thesis. Universitas Negeri Makassar.

Wibowo, N. (2016). Upaya peningkatan keaktifan siswa melalui pembelajaran berdasarkan gaya belajar di SMK Negeri 1 Saptosari. Jurnal Electronics, Informatics, and Vocational Education, 1(2), 128-139.

Yulianis., Maharani, A. D., \& Susanti, S. (2019). Analisis kemampuan berpikir tingkat tinggi pada materi sistem pertahanan tubuh siswa kelas XI SMA. Bioconcetta, 5(2), 105-112.

Zamzami., Sakdiah., \& Nurbaiza. (2020). Analisis faktor kesulitan belajar mata pelajaran biologi siswa kelas X SMA Negeri 1 Krueng Barona Jaya Kabupaten Aceh Besar. Jurnal Dedikasi Pendidikan, 4(1), 123-133.

Zeidan, A., 2010. The relationship between grade 11 Palestinian attitudes toward biology and their perceptions of the biology learning environment. Int. J. Sci. Maths. Educ., 8, 783800 . 